\title{
Cairo Conference and the Dispute of Diaoyu Islands
}

\author{
Yufeng Liu \\ School of Humanities, Qingdao Agricultural University, Qingdao, 266109, China
}

Keywords: The Cairo Conference. The Diaoyu Islands. America

\begin{abstract}
Cairo Conference, the conference held by modern China and world powers under the circumstance that China was poor and weak, has an epoch-making significance. It was the first meeting that China was treated as an equal sovereign country, which helped China benefit a lot. The Cairo Declaration has significant influence on the ownership of disputed Diaoyu Islands. On the 70th anniversary of the successful holding of the Cairo Conference, it has strong legal significance and realistic value to study the Cairo Conference and the dispute of Diaoyu Islands in the situation of the increasing tension among the disputed islands.
\end{abstract}

\section{The Cairo Declaration has great legal value to confirm the ownership of Diaoyu Islands.}

The international law validity of the Cairo Declaration has sufficiently proved this fact, but lacks specific argument about the fact that the Diaoyu Islands is included in the revertible territory of Republic of China requested in the Cairo Declaration. The basis of the fact that the Diaoyu Islands is included in the revertible territory of Republic of China can be found out in following aspects:

\section{Diaoyu Islands was stolen by Japan}

The Cairo Declaration explicitly stipulates that the purpose of three countries is to deprive all the islands captured or occupied in force from the Pacific Ocean by Japan since the beginning of the first world war in 1914; the territory stolen by Japan should be returned to the Republic of China, including the northeast four provinces, Formosa and the Penghu Islands; Japan shall be deported from any other land it seized in force or greed (The Cairo Declaration has no official Chinese version, and the above is the general translation). The stipulation used "stolen" to describe the territory occupied by Japan, which was particularly appropriate on Diaoyu Island Issue.

In English version, the stipulation used "stolen" to emphasis that the Diaoyu Islands was seized in force by Japan. Some Japanese regards the Diaoyu Islands as terra nullius, but there are many solid evidences to prove that this is wrong. Diaoyu Islands was definitely stolen by Japan under the circumstance that China was poor and weak and had no strong ocean dominion sense.

Since 1885, having explored the Diaoyu Islands secretly, the county magistrate of Okinawa used to submit written documents to central government for many times, asking for setting up "national identity" on the islands. However, the Japanese government tacitly approved that the Diaoyu Islands belonged to the Qing Government. The Japanese government had more concern and restrained its behavior especially after Qing government set up General Navy Affairs Yamen (a government office in feudal China) and Taiwan Province to enhance its coast defense.

It was three months before the assignment of Treaty of Shimonoseki that the Japanese government, considering the failure of Qing government, held cabinet council to secretly include the Diaoyu Islands as a terra nullius into Okinawa. Japanese government, however, failed to declare its sovereignty to Diaoyu Islands, which had extreme inconformity to the action it did after occupying Daito islands to which the government declared its sovereignty immediately. The only reason to explain this is that Japanese government knew this was dishonorable and tried to cover it up on purpose. Moreover, the Japanese government did not make it public for a long time at home. Therefore, Japan definitely stole the Diaoyu Islands.

Diaoyu Islands is the affiliated island of Formosa that was explicitly mentioned in the Cairo Declaration. Therefore, as Formosa is mentioned, Diaoyu Islands must have been included.

There are abundant evidences to prove that Diaoyu Islands is the affiliated islands of Formosa. Affiliated Islands is not only a geographic concept, but also an administrative concept. Diaoyu 
Islands belongs to the continental island of Formosa on the geographical structure. Its geomorphic and geographic features indicate that Diaoyu Island locates on the continental shelf of the East China Sea as the natural extension of Formosa. Moreover, in terms of administrative concept, China is the first country to exercise the administrative jurisdiction of Diaoyu Islands. Hu Zongxian, the top general garrisoning the Southeast Coastal in Ming dynasty, and geographer Zheng Ruozeng compiled the Map Series about the Sea (1562) to compile the Diaoyu Islands and other islands into a coastal topographic map called the Map with Coastal Sea, Mountains and Islands and regarded it as the territory of China to garrison. This is one of the earliest written work to prove that China exerts effective jurisdiction over the Diaoyu Islands.

However, why did not the Cairo Declaration mention the "affiliated island" ? The second section in the Treaty of Shimonoseki regulated that Japan occupied Liaotung Peninsula, Formosa and its affiliated islands and Penghu Islands while the Cairo Declaration only enumerated the land that should be return to China. It is easily to find out that the listed lands in the Cairo Declaration included all the lands we lost from the Treaty of Shimonoseki through comparison. In order to confirm it strictly, the Cairo Declaration listed the key and conflicted territory so that Formosa and its affiliated islands which were lost from the Treaty of Shimonoseki were particularly referred to in the declaration to avoid leaving leftover problems.

Chiang Kai-shek wrote in his dairy that what a significant event and hope it was to return the northeast four provinces, Formosa and the Penghu Islands we had lost for 50 years or 12 years respectively under the declaration both by Great Britain and America as well as to guarantee the freedom and independence of Korea, which was even announced in the declaration. This was a significant foreign affair success from ancient to modern times. From then on, however, if we failed to endeavor, all these success were only a mere scrap of paper. In this dairy, Chiang used a number 50 which indicated that the Formosa mentioned in the Cairo Declaration corresponded to the Formosa and its affiliated islands in the Treaty of Shimonoseki.

In this situation, why did the declaration failed to list the Diaoyu Islands explicitly? Recently, the Diaoyu Islands issue attracts the world attention; 70 years ago when the Cairo Conference was held, however, the disputed islands was rarely noticed by the public. There were numerous islands stolen by Japan so it was impossible to list all those islands. Diaoyu Islands, the affiliated island of Formosa, was small and uninhabited, let alone the undiscovered fuel resources and the awareness about national sea power. Therefore, it was very common not to list it particularly, which had no influence on returning it to China.

\section{The indirect connection between the Cairo Conference and the dispute of Diaoyu Island.}

Cairo Conference, the conference held by modern China and world powers under the circumstance that China was poor and weak, has an epoch-making significance. It was the first meeting that China was treated as an equal sovereign country, which helped China benefit a lot. Some scholars named this conference as "the diplomacy summit of China during the world war. The main topic of the conference was to discuss the war cooperation towards Japan and the methods to deal with Japan after the war. There were no other regrets of this conference towards other disputed issues except for the Diaoyu Islands.

\section{The dispose of the Ryukyu Islands and the form of the dispute of Diaoyu Islands}

There is close connection between the Diaoyu Islands issue which is the core dispute among the relationship between China and Japan and the discussion and solution about the Ryukyu Islands. During the Cairo Conference, former American President Roosevelt used to suggest returning the Ryukyu Islands to China, but Chiang refused. The Chinese academics hold different views towards Chiang' s decision. Some of them are critical to Chiang' s behavior, considering that this decision left the door open for the future conflicts; others, however, regard this decision as a non-important variable. The suggestion by the America was just a kind of trial instead of its real thoughts and actions. The first opinion shows that there may be future trouble because of Chiang' s decision, but lacks 
evidence to prove that America would give the Ryukyu Islands to China while the second idea hold the opposite opinion.

As far as this article is concerned, it is a great pity that Chang refused America' s suggestion because there are sufficient evidences to prove that the conference was the best opportunity to expel Japan from the Ryukyu Islands. in July 1943, there were three strategies for China to choose towards the Ryukyu Islands issue: one is to give it back to China; one is to be managed under the international organization; and the third is to give it back to Japan. After analyzing Roosevelt' s basic judgment and attitude, the international circumstance then and the relationship between America and China, it is likely to ask America to give it back to China. The reasons are as follows:

First of all, the Ryukyu Islands did not belong to Japan, compared with which, China has deeper and more profound relationship with Ryukyu Islands. The Ryukyu Islands, from Han dynasty, was the maritime trade transfer station among China, Japan and Southeast Asian countries. The establishment system of Ryukyu was very similar with the bureaucracy system, the etiquette system and the educational system in Ming Dynasty. In accordance with the Memoir of the Ming Dynasty, during the 100 year from Hongwu the fifth year (AD 1372) to Chenghua the eighth year (AD 1472), the Ryukyu sent envoys to Ming for 248 times. Since Ming supported the development of the Ryutyu, it quickly got rid of the age of barbarism. However, Japan occupied the Ryukyu in force. Japan invaded the Ryukyu in 1609. After that, the Ryukyu was included in the Japanese territory in 1879 and was changed into Okinawa in the same year.

Secondly, America, the country played an important role in the Cairo Conference, tried it best to woo China. Before the conference, America expressed to respect China' s sovereignty, claiming to give up all the privilege acquired through unequal treaties and to urge other countries to imitate. On January 1st, 1943, Chongqing Kuomintang Government signed the contracts and exchange of notes with the America and the Great Britain respectively to cancel their extraterritoriality in China and to solve related problems. The Boxer Protocol was abolished, all the privilege given by this agreement shall be halted, and the China could take charge of the management of the international settlement in Shanghai and Xiamen again. All the privilege mentioned above shall be halted. The Great Britain and America proposed actively to return Chinese lands. Roosevelt, communicating with China privately, generously agreed to lend China one billion US dollars, and suggested to give the Ryukyu to China. All these indicated that the America is sincere to deepen the relationship with China.

Thirdly, the relationship between America and China was still stable when America started the de facto government control of the Ryukyu.

In April 1945, US army invaded the Ryukyu. In May, the army force control the Ryukyu directly. Meanwhile, America did not change his mind to build Chiang government as a pro-American government. The year 1948 was the turning point American China Policy. It was the time when the People' s Liberation Army led by the Party was invincible and the Kuomintang was destined to fail. Only at that time that there existed a serious difference among China Policy makers.

All mentioned above demonstrated that it was extremely likely to expel Japan from the Ryukyu Islands. Nevertheless, because of Chiang' s suspicion towards America, anxiety about his image in front of other countries and the number of lands given back beyond his expectation, he did not accept it, which left a pity to the later generations.

\section{The "American factors" in the dispute of Diaoyu Islands}

The Cairo Conference mentioned that the Ryukyu shall be managed by both China and America, but the development of the Ryukyu issue was beyond this regulation. In April 1945, US army occupied the Ryukyu and expelled Japan from the occupied territory including the Ryukyu Islands and Islands in the south of 30 degree north latitudes, which were then fully managed by US army directly. After that, the Ryukyu issue was totally around the interests of the US and followed the path under America' s control. America, so to speak, is the key factor for the form of the Diaoyu Islands issue.

The reason way America can take his own course was determined by various factors. Every time' s settlement of the international order was mainly guided by the victorious nations and major powers. 
At that time, the position of America was not to be questioned. In addition, the weak of national sea power, the change of civil war situation and the change of American China Policy conjointly resulted in the change of the solution of this issue compared with the original way settled in the conference. Chiang lost his control and the People' s Republic of China was hostile by America, which finally caused the Japan' s occupation of the Ryukyu Islands.

In April 1945, In April 1945, US army occupied the Ryukyu and expelled Japan from the occupied territory including the Ryukyu Islands and Islands in the south of 30 degree north latitudes, which were then fully managed by US army directly. In January 1946, US Joint Chiefs of Staff proposed more explicitly that the America would manage the islands to the north of 31 degree north latitudes and the islands between Kyushu and Taiwan as strategic regions. On April 2nd, 1947, the UN passed the proposal and made the Ryukyu, the Bonin Islands and other areas managed by Japan under the control of American strategic management. In 1951, the Great Britain and America signed the Japan Peace treaty in San Francisco privately. The third section in the treaty regulated that Japan agreed to give islands to the south of 29 degree north latitudes, including southeast islands, the Ryukyu Islands, the Daito Islands, the Widow islands, the Bonin Islands, the Nishino Island, the Volcano Islands, the Okino-tori Island and the Minami-tori Island under American management and to regard America as the only management administration. America has the right to exercise any administrative, legislative and management right on the territory, citizens and coastal. On December 25th, 1953, the Ryukyu government illegally included the Diaoyu Islands into its administrative region. On June 17th, 1971, America and Japan signed the agreement to give the Ryukyu Islands back to Japan (the Agreement between America and Japan about the Ryukyu Islands and Daito Islands), which included the Diaoyu Islands into the Ryukyu and gave the management right to Japan. This finally resulted in the dispute of Diaoyu Islands.

\section{The cautionary significance of the Cairo Conference on the dispute of Diaoyu Islands}

\section{We must be on guard of the interference of the hegemonism and power politics towards the solution of the dispute of Diaoyu Islands}

The Cairo Conference helped China to get rid of the humiliation having existed for more than 100 years and maintain the territorial sovereignty. Nevertheless, China, compared with Great Britain and America, has no sense of hegemonism. Even if America proposed to give the Ryukyu Islands to China, Chiang was unwilling to receive. On the contrary, what America did towards the Diaoyu Islands Issue was typical action of hegemonism and power politics.

Throughout the history, all the international orders, including the Order of the Westphalia, the Order of the Vienna and the Versailles-Washington Order, were formed under the hegemonism and the power politics. Victorious major powers maintained other countries' destiny arbitrarily. During the Cairo Conference, there were still apparent power politics on the Great Britain and America, that is, the conference was initiated to hold by America and the Great Britain and America had great influence on the disposal of Japan, easily solving the historical problem perplexing China for more than 100 years.

Chiang used to point out that the thing that he had never imagine was that the humiliation China suffered for more than 100 years was totally wiped away immediately by several great politicians during the conference, which brought him a new experience about power politics. After 1945, it was the American hegemonism that made the Diaoyu Islands into Japan step by step. America, of course, was the Black Hand behind the dispute of Diaoyu Islands who supported Japan. We must always alert and restrain the interference by the major powers. During the Cairo Conference, the reason America wooed Chiang was on the basic to cultivate pro-American force. The international circumstance has changed a lot that there is no cooperation and competitive relationship instead of alliance relationship between America and China. The alliance relationship between America and Japan is still very solid. In the current situation, we must find out an effective method to contain the support of Japan by America and other major powers. 
China will not become a power politics, but must find out the way to be wealthy and strong The national strength is the material basis for a country to play an important role on the international stage. It decides the country' $s$ international position in society and is the strong background of foreign behavior. The Cairo Conference obviously expressed the significance of the strong of the country. Chiang participated in the conference as a leader of a weak and poor country. Therefore, he was unwilling to attend the meeting until Roosevelt invited him for many times. Chiang wrote in his dairy that Roosevelt invited him to attend the conference with other three countries and would meet with him several days earlier before the meeting individually. He considered that he was only the foil and has no significance. Therefore, he used to refuse to attend it. In the introspection record written at the same time Chiang wrote that he was not willing to receive that undeserved reputation or the human relationship so he refused it again. It can be seen that Chiang was not confident faced with a poor and weak country. Therefore, he kept a low profile and low expectation in the conference, and finally refused to receive the Ryukyu Islands. China will not become power politics and follow the path of peaceful development. Only with wealth and strength can the country contain other power politics to the large extent and restrain their ambition.

The foundation among the development of countries is the national interest

The foundation among the development of countries is the national interest. National interest is the most basic motivaiton for all nations to take foreign behaviors. Before and after the Cairo Conference, the behaviors among countries to maintain their own interests reflected sufficiently. In order to cultivate the Chiang Government as the pro-American government, America wooed the Chiang at the very beginning, then changed his attitude from helping China to restrain Japan into helping Japan to restrain China, and finally gave the Diaoyu Island to Japan; as for Great Britain, he excluded China extremely because of its interest in China; the Soviet Union refused to attend the conference for his own interest. The recognition of the fact that the foundation among the development of countries is the national interest can help us to set up effective foreign policies. Since it is the own interest that determines the attitude of power politics towards Diaoyu Island issue, the interest is the only way to contain the interference of power Politics.

The Diaoyu Islands is China' s territory, and the sovereignty must be defended

The position of China and Japan on the Diaoyu Islands issue is irreconcilable. Japan tries to occupy the Diaoyu Islands permanently by all means. If we make any concessions, it will be much more insatiable. Diaoyu Islands has always been our territory and we must defend our sovereignty. China, as a peace-loving country, will not make any conflicts initiatively. However, if our sovereignty is threatened, we will make no concession.

\section{References}

[1] Lee. USA factors and the Diaoyu Islands issue back in Ryukyu. Journal of Tsinghua University,.2012 (6)

[2] Wang Weihu. Exploring America' s Influence on the Diaoyu Islands Dispute between China and Japan. Journal of Heilongjiang institute of education. 2011 (10)

[3] Yang moderate. America factor in Taiwan issue. Journal of Henan Normal University (PHILOSOPHY AND SOCIAL SCIENCE EDITION). 2002 (03)

[4] Li Hua. Jiang Jieshi and the Cairo conference. Social Science Front. 1995 (2)

[5] (Su) Wo Ron Geoff, Li Fanghua, et al. A critical biography of Jiang Jieshi. Social Sciences Academic Press, 1991

[6] Fang Lianqing editor. History of modern international relations. Peking University press, 1990

[7] Chu Jingtao. The Diaoyu Islands and the Ryukyu attribution. Jianghai Academic Journal. 2012 (06)

[8] Yi Zong. Beginning and end of the Diaoyu island problem. Journal of news report. 2004 (02) 
[9] Liu Chunming. Treaty of Maguan" and the Diaoyu Islands. Pacific Journal. 2012 (07)

[10] Zheng Hailin. The history of the Diaoyu islands sovereignty and international law analysis. China's borderland history research. 2011 (04)

[11] Li Yanna. Franklin Roosevelt's custody system scheme with China. Journal of Shandong Normal University (SOCIAL SCIENCE EDITION). 2011 (01)

[12] Li Yanna. Comparison of "Mandate system" and "the international trusteeship system". History teaching (the version). 2009 (08)

[13] Wang Hui. Cold war sign: Chiang kai-shek and the problem of ryukyu in Cairo conference-The ryukyu: war memory, social movements and the historical interpretation corrections. Open era. 2009 (05)

[14] Guo Yonghu. On the Diaoyu Islands Dispute "America factor" of the history of. China borderland history and geography studies of. 2005 (12)

[15] Su Zhiliang, Li Yunbo. The Cairo conference and the Diaoyu Islands issue of "Cairo declaration" -in commemoration of the 70 anniversary published. History teaching problems. 2013(4) 